\title{
Nocardia pinensis sp. nov., an Actinomycete Found in Activated Sludge Foams in Australia
}

\author{
By LINDA L. BLACKALL,${ }^{*} \dagger$ J. H. PARLETT,${ }^{3}$ A. C. HAYWARD, ${ }^{1}$ \\ D. E. MINNIKIN ${ }^{3}$ P. F. GREENFIELD ${ }^{2}$ AND ANNE E. HARBERS ${ }^{2}$ \\ ${ }^{1}$ Department of Microbiology, and ${ }^{2}$ Department of Chemical Engineering, \\ University of Queensland, St. Lucia 4067, Queensland, Australia \\ ${ }^{3}$ Department of Organic Chemistry, The University, Newcastle upon Tyne NEI 7RU, UK
}

(Received 8 February 1989; accepted 15 February 1989)

\begin{abstract}
A new nocardioform actinomycete was isolated by filament micromanipulation during the course of a study into foaming in activated sludge plants in Australia. It constitutes the second most prevalent foaming organism in Australia after Nocardia amarae. These two foaming organisms can be differentiated morphologically, biochemically and chemotaxonomically. The microscopic appearance of the filaments of the new taxon resembles a pine tree. The filaments are Gram-positive, non-acid-fast, non-motile, non-sheathed and about $0.5-1.0 \mu \mathrm{m}$ in diameter. On a complex medium, the colonies are orange, opaque, macroscopically dry and friable, microscopically moist and shiny, with a pasty texture and an entire edge. The strains are positive for catalase, oxidase and urease and are oxidative in their metabolism of glucose. No strain could degrade hypoxanthine, xanthine, tyrosine, casein, gelatin or aesculin and none could grow with lysozyme. The strains contain peptidoglycan type Al $\gamma$, cell wall type IV, whole cell sugar pattern type $\mathrm{A}$, phospholipid type PII, menaquinones $\omega$-cyclo-MK-8 $\left(\mathrm{H}_{4}\right)$, fatty acids comprising straight chain saturated and unsaturated acids and tuberculostearic acid, and mycolic acids with 58-64 carbons containing substantial amounts of unsaturated chains in the 2-position. The name Nocardia pinensis has been chosen for the new taxon because of the pine tree like appearance of the organism on microscopy. The type strain, UQM3063, is deposited at the University of Queensland, Department of Microbiology Culture Collection.
\end{abstract}

\section{INTRODUCTION}

The formation of stable, dark, viscous foams or scums on the surfaces of the aeration tank section of activated sludge processes was first reported in 1969 (Anonymous, 1969). The stable foam is grey to brown-cream in colour, quite heavy in consistency, up to $30 \mathrm{~cm}$ deep, and watersprays applied to the surface have little effect upon its collapse (Lechevalier, 1975; Pipes, 1978; Dhaliwal, 1979). The build up of scum in an activated sludge plant does not appear to accompany any specific plant design with the exception of the aeration system (Hartley, 1982); however, operational mode (Ferguson, 1980; Pipes, 1978; Hartley, 1982), influent type (Lechevalier, 1975; Pipes, 1978; Dhaliwal, 1979; Nelson, 1979; Tricker \& Thorpe, 1979), and specific weather patterns (Lechevalier, 1975) have been cited as precipitating factors. Operational problems have been attributed to the scum, and its added financial cost to the plant is as a result of extra personnel required for scum control and clean-up.

When the scum is examined microscopically, many Gram-positive, branching filamentous bacteria are commonly observed (Lechevalier, 1975). Selective accumulation of the actinomycetes in the foam over that in the mixed liquor is common. The predominant organism associated with foams was isolated and identified as Nocardia amarae by Lechevalier \&

$\dagger$ Present address: School of Microbiology, University of New South Wales, PO Box 1, Kensington 2033, Australia.

Abbreviations: YG, yeast glucose agar; TYG, tryptone yeast extract agar. 
Lechevalier, (1974). This is still regarded as the dominant foaming organism; however, Rhodococcus rhodochrous (Lemmer \& Kroppenstedt, 1984) and 'Microthrix parvicella' (Blackbeard et al., 1986; Hart, 1985) are also implicated.

Foaming in activated sludge plants was investigated in Queensland, Australia, and during the course of the study, a unique actinomycete was isolated. It differed from all the previously recognized foaming organisms and was therefore fully characterized. This paper describes the new actinomycete for which the name Nocardia pinensis sp. nov. is proposed.

\section{METHODS}

Isolation and identification. The strains used in the study are listed in Table 1. All fresh isolates came from Queensland, Australia. Isolation of the actinomycetes was by micromanipulation using the Skerman micromanipulator (Skerman, 1968). Bacterial mycelium was manipulated to either yeast glucose agar (YG) containing (per litre), $10 \mathrm{~g}$ yeast extract, $10 \mathrm{~g}$ glucose and $15 \mathrm{~g}$ agar, or to tryptone yeast extract agar (TYG) containing (per litre), $3 \mathrm{~g}$ tryptone, $5 \mathrm{~g}$ yeast extract, $5 \mathrm{~g}$ glucose and $15 \mathrm{~g}$ agar. The $\mathrm{pH}$ of all media was adjusted to $7 \cdot 0$ unless otherwise stated and sterilization was at $121^{\circ} \mathrm{C}$ for $15 \mathrm{~min}$.

Extraction of cellular DNA was unsuccessful. A summary of the methods used and the possible reasons for the failure to extract DNA are presented in the Discussion.

Inoculum preparation. For all tests, unless otherwise stated, inoculum was grown on solid TYG for $7 \mathrm{~d}$ (reference strains) or $21 \mathrm{~d}$ (Nocardia pinensis) at $28^{\circ} \mathrm{C}$ in the dark. Biomass from the plates was vortexed in a bottle containing $5-10 \mathrm{ml}$ sterile distilled water and a few $0.25 \mathrm{~mm}$ diameter glass beads and the resulting suspension used as inoculum.

Microcolony and cell morphology. (a) Light microscopy. Inoculum for cultures came from 7 or $21 \mathrm{~d}$ old TYG plate cultures and suspensions were prepared such that when the cells were inoculated onto the TYG media, well separated cells were visible. Microcolonies of cells were photographed with Kodak Plus X pan ASA 125 black and white film using an Olympus BHS microscope with a BH2-PC phase contrast turret condenser and a PM-10AD photomicrographic system.

(b) Electron microscopy. Cells of $N$. pinensis were taken from the surface of TYG plates, negatively stained with $1 \%(\mathrm{w} / \mathrm{v})$ phosphotungstic acid ( $\mathrm{pH} \mathrm{6.5)} \mathrm{for} 20 \mathrm{~s}$ and examined by transmission electron microscopy using an Hitachi H-800 electron microscope.

Staining reactions. The Gram reaction (Skerman, 1967; Cruickshank et al., 1975), presence of sudanophilic inclusions (Burdon, 1946), presence of polyphosphate inclusions (Cruickshank et al., 1975) and determination of acid fastness (Cruickshank et al., 1975) were done with all strains with biomass from TYG plates.

Biochemical tests. The test media were incubated at $28^{\circ} \mathrm{C}$ and, unless otherwise stated, read at 14 and $21 \mathrm{~d}$ for the $N$. pinensis strains and at 7 and $14 \mathrm{~d}$ for the remainder of strains.

Acid production from carbohydrates. Tryptone yeast extract medium $[0.1 \%(\mathrm{w} / \mathrm{v})$ tryptone; $0.3 \%(\mathrm{w} / \mathrm{v})$ yeast extract; $1.5 \%(\mathrm{w} / \mathrm{v})$ agar] with $5 \mathrm{ml} 10 \%(\mathrm{w} / \mathrm{v})$ bromothymol blue $\mathrm{l}^{-1}$ was the basal medium for these tests. Carbon sources were at $0.5 \%(\mathrm{w} / \mathrm{v})$. The medium was dispensed into tubes and set as slopes. Semi-solid media with glucose were also used and were stab inoculated. All tests were read at $28 \mathrm{~d}$.

Degradation of macromolecules. Concentrations of the macromolecules were as in Gordon (1967) and the basal medium was TYG. Inoculum was spotted onto the solid media. For aesculin hydrolysis, the method of Sneath (1956) was slightly modified such that the medium included tryptone and yeast extract in place of peptone.

Growth in the presence of inhibitors. Mitomycin $\mathrm{C}\left(5 \mu \mathrm{g} \mathrm{ml}^{-1}\right.$; Sigma), isonicotinic acid hydrazide (isoniazid $200 \mu \mathrm{g} \mathrm{ml}^{-1}$; Sigma), rifampicin $\left(20 \mu \mathrm{g} \mathrm{ml}^{-1}\right.$; Sigma) and 5-fluorouracil $\left(20 \mu \mathrm{g} \mathrm{ml}^{-1}\right.$; Sigma) were incorporated into TYG. All antibiotics except isoniazid were filter-sterilized prior to addition to the cooled, sterile basal medium. Isoniazid was added to the basal medium prior to sterilization. The inoculum was spotted on to the solid media.

Tween hydrolysis. TYG containing $0.01 \%(\mathrm{w} / \mathrm{v}) \mathrm{CaCl}_{2} .2 \mathrm{H}_{2} \mathrm{O}$ was the basal medium for this test, which was based on the method of Sierra (1957). Tweens were incorporated at $1 \%(\mathrm{w} / \mathrm{v})$ and spot inoculation was used.

Detection of urease. TYG (1 litre) with $1.2 \mathrm{ml}$ of $10 \%$ (w/v) phenol red and $10 \mathrm{ml}$ of $20 \%$ (w/v) filter sterilized urea was the medium for this test, which was based on the method of Christensen (1946).

Nitrite formation from nitrate. The method of Skerman (1967) was used for all strains and liquid TYG was the basal medium.

Lysozyme resistance. The method of Gordon \& Barnett (1977) was used for this test and growth was determined after 7 and $21 \mathrm{~d}$. Ability to grow in glycerol broth without lysozyme was used as a control.

Catalase and oxidase test. The catalase test was carried out by adding a drop of $10 \mathrm{vol} . \mathrm{H}_{2} \mathrm{O}_{2}$ onto the growth on a TYG plate. Instant emission of gas bubbles was positive. The oxidase test was determined by smearing biomass from a TYG plate onto filter paper impregnated with a drop of the oxidase reagent from a Marion oxidase dropper. A blue black colouration to the reagent in $10-20 \mathrm{~s}$ was positive. 
Table 1. Strains used in this study

The first 12 strains are the new actinomycete whilst the remainder are used as reference strains.

Name

Nocardia pinensis

Nocardia pinensis

Nocardia pinensis

Nocardia pinensis

Nocardia pinensis

Nocardia pinensis

Nocardia pinensis

Nocardia pinensis

Nocardia pinensis

Nocardia pinensis

Nocardia pinensis

Nocardia pinensis

Nocardia amarae

Nocardia amarae

Nocardia amarae

Nocardia amarae

Nocardia amarae

Nocardia amarae

Rhodococcus equi

Rhodococcus equi

Rhodococcus rhodochrous

Rhodococcus rhodochrous

'Gordona aurantiaca'

$$
\text { Laboratory }
$$$$
\text { no. }
$$

Reference/isolation site*

UQM3063
NM41
NM55b
UQM3064
NM101
NM102
NM109
NM110b
NM118
NM167b
NM168b
NM170
UQM2058

UQM2810

NM26

NM86

NM206

NM296

UQV1092

UQV1002

UQM2807

UQM2808

UQM2809

$\quad$ Reference/isolation site*
Bellbowrie STP
Bellbowrie STP
Bundamba STP
Bundamba STP
Burleigh Park STP
Burleigh Park STP
Yandina STP
Bundamba STP
Hayman Island STP
Merrimac STP
Loganholme STP
Nudgee STP
Lechevalier \& Lechevalier (1974); sewage
plant; type strain
Lemmer \& Kroppenstedt (1984); sewage plant
Tingalpa STP
Ferny Hills STP
Brackenridge STP
Townsville Golf Course STP
Equine lung
Porcine lymph node
Lemmer \& Kroppenstedt (1984); sewage plant
Lemmer \& Kroppenstedt (1984); sewage plant
Lemmer \& Kroppenstedt (1984); sewage plant

Source $†$

Fresh isolate Fresh isolate

Fresh isolate

Fresh isolate

Fresh isolate

Fresh isolate

Fresh isolate

Fresh isolate

Fresh isolate

Fresh isolate

Fresh isolate

Fresh isolate

ATCC 27808

DSM 43602

Fresh isolate

Fresh isolate

Fresh isolate

Fresh isolate

UQV

UQV

DSM 43583

DSM 43601

DSM 43599

* STP, sewage treatment plant.

† ATCC, American Type Culture Collection, Rockville, Maryland, USA; DSM, Deutsche Sammlung von Mikroorganismen, Göttingen, FRG; UQM, Culture Collection, Department of Microbiology, University of Queensland, Brisbane, Australia; UQV, Culture Collection, Department of Veterinary Pathology and Public Health, University of Queensland, Brisbane, Australia.

Cell wall components. (a) Amino acids and carbohydrates. The methods followed were those of Harper \& Davis (1979) for amino acids and of Staneck \& Roberts (1974) for carbohydrates. For both, TLC on cellulose-coated aluminium sheets $(20 \times 20 \mathrm{~cm})($ Merck no. 5552) was used and 5-10 1 l volumes of hydrolysates were applied to the sheets.

(b) Fatty acids, mycolic acids, polar lipids and menaquinones. The $N$. pinensis strains were grown for $21 \mathrm{~d}$ on sterile, $0.45 \mu \mathrm{m}$ pore size, cellulose acetate membrane filters on the surface of TYG plates. The membranes were lifted from the plates and the cells scraped into sterile $5 \mathrm{ml} \mathrm{McCartney} \mathrm{bottles} \mathrm{and} \mathrm{lyophilized} \mathrm{without}$ cryoprotection. Lipids were extracted according to Minnikin et al. (1984).

For polar lipids, two dimensional TLC on aluminium backed silica gel sheets was used (Merck no. 5554). The first direction solvent was chloroform/methanol/water $(60: 30: 6, \mathrm{v} / \mathrm{v})$ and the second chloroform/acetic acid/methanol/water $(40: 25: 3: 6, \mathrm{v} / \mathrm{v}$ ). Different spray systems were used for the different polar lipids (Dobson $e t$ al., 1985).

Menaquinones were isolated by two dimensional TLC (Nahaie et al., 1984) and identified by mass spectrometry (Collins et al., 1977).

Mycolic acid analyses followed the methods of Minnikin et al. $(1975,1980)$ and mass spectrometry of the tertbutyldimethylsilyl ethers of the isolated methyl mycolates provided ranges of molecular masses and sizes of the chains in the 2-position (Minnikin et al., 1982).

Whole cell acid methanolysis and isolation by TLC of the fatty acid methyl esters (FAMEs) was carried out by the method of Minnikin et al. (1980). The FAMEs were identified using a Shimadzu GC Mini 2 flame ionization chromatograph fitted with both a $25 \mathrm{~m} \mathrm{OV}-1$ fused silica bonded column (Alltech) and a $50 \mathrm{~m}$ Silar $10 \mathrm{C}$ fused silica non-bonded column (Alltech); the injected sample was split between both columns. The operating temperature was programmed from 100 to $200^{\circ} \mathrm{C}$ at $5{ }^{\circ} \mathrm{C} \mathrm{min}-1$ and peaks quantified using a Shimadzu CE $1 \mathrm{~B}$ integrator.

API ZYM determinations. The API ZYM system was used according to the manufacturer's (API) specifications. Nineteen enzymes were tested per gallery; galleries were incubated for $6 \mathrm{~h}$ at $28^{\circ} \mathrm{C}$ in the dark prior to detection. 
Suspensions in sterile distilled water (described above) were used as inocula. $N$. pinensis strains were cultured on TYG media whereas the reference strains were cultured on YG media.

Determination of pigment spectra. $N$. pinensis biomass from 21 -d-old TYG plate cultures was harvested into chloroform and ethanol and vigorously shaken to extract the orange pigment. A few drops of $20 \%(\mathrm{w} / \mathrm{v}$ ) $\mathrm{KOH}$ were added to the ethanol extract to determine the presence of flexirubin-type pigments (Reichenbach et al., 1981). The chloroform extract was scanned from $200 \mathrm{~nm}$ to $800 \mathrm{~nm}$ using a Beckman DU-8 spectrophotometer.

Growth temperature determinations. Slopes of TYG were inoculated with a drop of bacterial suspension and placed into a variable temperature incubator. The temperatures selected for the incubator ranged from $11^{\circ} \mathrm{C}$ to $36^{\circ} \mathrm{C}$. Tubes were examined every $3 \mathrm{~d}$ for $21 \mathrm{~d}$.

Determination of growth on different media and under different atmospheres. An extensive range of complex and defined media were evaluated for the ability to support the growth of $N$. pinensis. Incubation of all media was at $28^{\circ} \mathrm{C}$ in the dark and growth assessment was made after $21 \mathrm{~d}$. Cultures on TYG were incubated in the light, dark, anaerobically, microaerophilically, in a candle jar and in an atmosphere containing $5 \%(\mathrm{v} / \mathrm{v}) \mathrm{CO}_{2}$.

\section{RESULTS}

\section{Microcolony and cell morphology}

Results from the $N$. amarae strains isolated from the activated sludge plants agreed with the description given by Lechevalier \& Lechevalier (1974). Filament fragments of $N$. pinensis in activated sludge foams and mixed liquors resembled pine trees and as such could be distinguished from $N$. amarae (Fig. 1). $N$. pinensis strains took 10-21 d to produce colonies that were about 1-2 $\mathrm{mm}$ in diameter on TYG; however, the growth rate was variable for no apparent reason. On some occasions the strains produced $2 \mathrm{~mm}$ colonies in 9-10 d whilst on others, the same strains took $21 \mathrm{~d}$ for colonies of the same size to develop. The $N$. pinensis strains on TYG were orange, opaque, macroscopically dry and friable, microscopically moist and shiny, not adherent to the agar, difficult to emulsify or subculture, circular with an entire edge. The majority of the colonies were approximately $1 \mathrm{~mm}$ in diameter; however, large colonies approximately 3-4 mm in diameter also occurred. The strains of $N$. pinensis grew in liquid TYG medium as macroscopically visible, orange coloured colonies in the slightly turbid liquid.

The mycelium of $N$. pinensis did not fragment in undisturbed cultures and secondary branching was rare to absent. Aerial mycelium was not visible to the naked eye; however, short branched and unbranched aerial hyphae could be seen microscopically. No specialized morphological structures have been noted (Figs. 2 and 3).

Examination of microcolonies showed the presence of phase bright spherical regions in the mycelium of $N$. pinensis in terminal and intercalary positions. The Gram-positive, septate mycelia of $N$. pinensis tapered after branch points.

\section{Staining reactions and biochemical tests}

The biochemical test results and the staining reactions for the $N$. pinensis strains and for the reference strains are shown in Table 2.

\section{Cell wall components}

All $N$. pinensis strains contained arabinose, galactose, glucose and ribose as the cell wall carbohydrates and meso-diaminopimelic acid (DAP), alanine and glutamic acid as the cell wall amino acids. The fatty acids present in the strains are shown in Table 3 and the mycolic acids are shown in Table 4.

All the mass spectra of the mycolic acid derivatives contained peaks at $m / z 381,355$ and 353 , in the approximate ratios $1 \cdot 0,0 \cdot 5$ and $0 \cdot 25$, respectively. These fragments are due to cleavage between carbons 3 and 4, followed by loss of 58 mass units (2-methylpropane), corresponding to hexadecenyl, tetradecanyl and tetradecenyl chains in the 2-position. If the mycolic acid methyl esters were analysed by pyrolysis gas chromatography (Lechevalier \& Lechevalier, 1974; Goodfellow et al., 1982), they would release major amounts of methyl octadecenoate and lesser proportions of methyl hexadecanoate and hexadecenoate.

Strains UQM 3064, NM110b, NM167b and NM41 were found to contain lipoquinones whose mass spectra had intense peaks at $m / z 187$ and 225 consistent with a normal 2-methyl-1,4- 


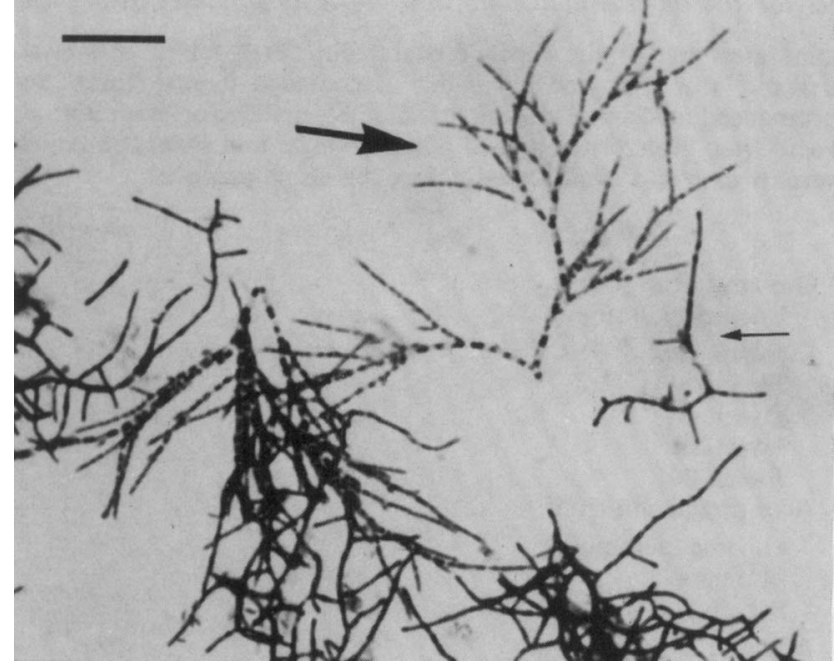

Fig. 1. Mycelial fragments of $N$. pinensis (large arrow) and $N$. amarae (small arrow) in a scum sample from Bundamba Sewage Treatment Plant. Bar, $20 \mu \mathrm{m}$.
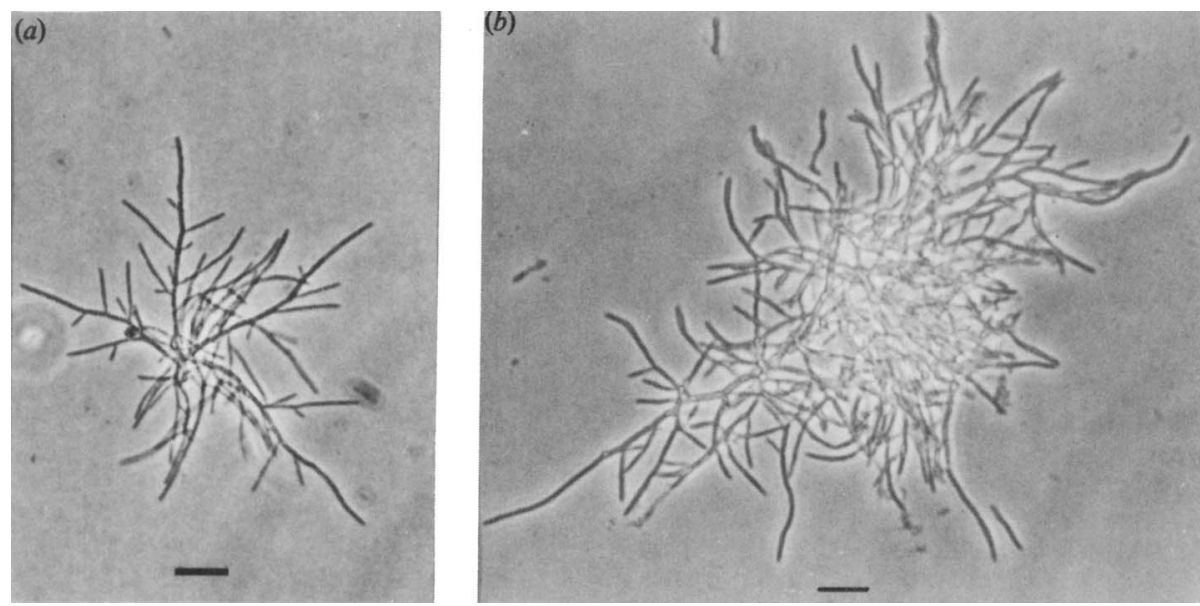

Fig. 2. Microcolonies of $N$. pinensis NM41 growing on TYG at $28^{\circ} \mathrm{C}$. (a) $24 \mathrm{~h}$ incubation. (b) $3 \mathrm{~d}$ incubation. Bars, $10 \mu \mathrm{m}$.

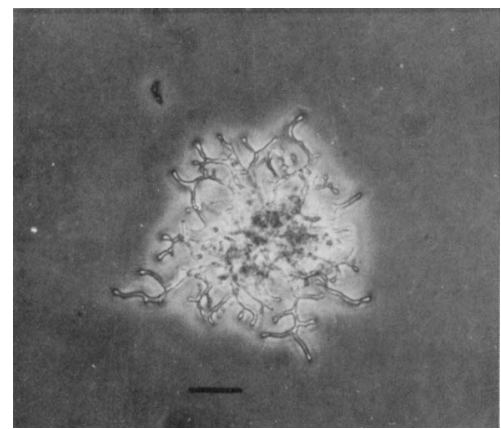

Fig. 3. Microcolony of $N$. amarae isolate NM86 grown on $\mathrm{YG}$ at $28^{\circ} \mathrm{C}$ for $24 \mathrm{~h}$. Bar, $10 \mu \mathrm{m}$. 
Table 2. Results for the biochemical and staining tests for the strains used in this study

None of the strains grew in the presence of rifampicin $\left(20 \mu \mathrm{g} \mathrm{ml}^{-1}\right)$, mitomycin-C $\left(5 \mu \mathrm{g} \mathrm{ml}^{-1}\right)$, 5-fluorouracil $\left(20 \mu \mathrm{g} \mathrm{ml}^{-1}\right)$ or lysozyme $\left(50 \mu \mathrm{g} \mathrm{m}^{-1}\right)$; degraded hypoxanthine, xanthine, tyrosine, casein or gelatin; produced acid from glucose (anaerobic), maltose or mannitol; were acid-fast. All strains produced acid from glycerol; contained polyphosphate and sudanophilic inclusions; grew in glycerol broth; were oxidase and catalase positive; were Gram-positive.

Test

Growth in the presence of: Isoniazid $\left(200 \mu \mathrm{g} \mathrm{ml}^{-1}\right)$

Lipolysis of :

Tween 20

Tween 40

Tween 60

Tween 80

Acid production from:

Glucose (aerobic)

Mannose

Salicin

Aesculin hydrolysis

Nitrate $\rightarrow$ Nitrite

\section{N. amarae $^{*} \quad$ N. pinensis $\dagger$}

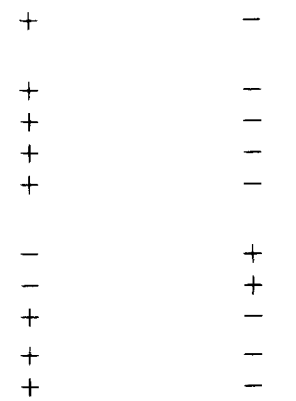

* $N$. amarae strains were UQM2058, UQM2810, NM26 and NM86.

$\dagger N$. pinensis strains were all those listed in Table 1 except that NM55b was omitted from the acid production from glycerol, maltose, mannitol, mannose and salicin tests.

Table 3. Percentage fatty acid composition of strains of $N$. pinensis

\begin{tabular}{|c|c|c|c|c|c|c|c|}
\hline \multirow[b]{2}{*}{ Strain } & \multicolumn{7}{|c|}{ Fatty acid type* } \\
\hline & $16: 1$ & $16: 0$ & $17: 1$ & $17: 0$ & $18: 1$ & $18: 0$ & TBS \\
\hline UQM3063 & $15 \cdot 72$ & $29 \cdot 80$ & $2 \cdot 43$ & 3.56 & $27 \cdot 03$ & 8.98 & 12.47 \\
\hline NM41 & $18 \cdot 34$ & $28 \cdot 85$ & 2.04 & 1.53 & $20 \cdot 44$ & $3 \cdot 19$ & $25 \cdot 60$ \\
\hline UQM3064 & $20 \cdot 29$ & 27.43 & 0.88 & 0.99 & $28 \cdot 84$ & 3.88 & $15 \cdot 57$ \\
\hline UQM3064 & $16 \cdot 30$ & $26 \cdot 78$ & $3 \cdot 16$ & 1.87 & $29 \cdot 19$ & 5.00 & $13 \cdot 16$ \\
\hline NM101 & $15 \cdot 23$ & $26 \cdot 23$ & $5 \cdot 33$ & 6.43 & $27 \cdot 41$ & 6.65 & $12 \cdot 71$ \\
\hline NM109 & $15 \cdot 07$ & $29 \cdot 16$ & $2 \cdot 34$ & $2 \cdot 29$ & $26 \cdot 03$ & $6 \cdot 27$ & $18 \cdot 83$ \\
\hline NM110b & $17 \cdot 59$ & $19 \cdot 92$ & $2 \cdot 59$ & $2 \cdot 10$ & $32 \cdot 36$ & 6.97 & 12.91 \\
\hline NM118 & $17 \cdot 69$ & $30 \cdot 30$ & $1 \cdot 37$ & 1.46 & $26 \cdot 43$ & $4 \cdot 90$ & 17.85 \\
\hline NM167b & $17 \cdot 38$ & $24 \cdot 90$ & $3 \cdot 30$ & 1.68 & $22 \cdot 20$ & $4 \cdot 21$ & $19 \cdot 12$ \\
\hline NM $168 \mathrm{~b}$ & $10 \cdot 70$ & $21 \cdot 42$ & $4 \cdot 37$ & $5 \cdot 72$ & $20 \cdot 61$ & $7 \cdot 88$ & $14 \cdot 20$ \\
\hline NM170 & - & $40 \cdot 67$ & - & $15 \cdot 19$ & $6 \cdot 47$ & $13 \cdot 92$ & 23.74 \\
\hline
\end{tabular}

-, None detected.

* $16: 0,17: 0$ and $18: 0$ denote hexadecanoic, heptadecanoic and octadecanoic acids; $16: 1,17: 1$ and $18: 1$ denote hexadecenoic, heptadecenoic and octadecenoic acids; TBS denotes 10-methyloctadecanoic acid (tuberculostearic acid).

naphthoquinone ring system (Collins et al., 1977). Molecular ions at $m / z 720$ corresponding to a $\mathrm{C}_{51} \mathrm{H}_{76} \mathrm{O}_{2}$ tetrahydrogenated menaquinone with eight isoprene units were observed (Howarth et al., 1986). The mass spectra also contained significant fragments at $m / z 584$ representing loss of a terminal cyclized 2-isoprene moiety. These results are consistent with good representatives of Nocardia (Collins et al., 1977).

Strains UQM3064, NM167b, NM110b, NM41, NM109 and NM118 possessed phosphatidylethanolamine, phosphatidylinositol, phosphatidylinositol mannosides and diphosphatidylglycerol as the polar lipids. These strains are therefore representative of phospholipid group PII (Goodfellow \& Lechevalier, 1986). Strains not listed in the tables or the text were not analysed. The lipid chemotaxonomy indicates membership of the genus Nocardia (Goodfellow \& Lechevalier, 1986). 
Table 4. Number of carbons and double bonds in the mycolic acids from the mass spectra of the mycolates of $N$. pinensis strains

The main component is denoted by +++ , any component greater than $50 \%$ of the main peak by ++ and all other significant components by + .

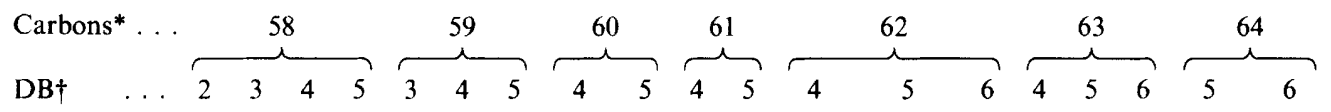

Strain

\begin{tabular}{|c|c|c|c|c|c|c|c|c|c|c|c|c|c|c|c|c|c|c|c|}
\hline UQM3064 & & + & + & + & & & & + & + & + & + & & $+t+$ & + & & + & + & ++ & $+t$ \\
\hline UQM3064 & & + & + & + & & + & + & $+t$ & + & + & + & + & $+t+$ & & + & + & + & + & + \\
\hline NM167b & + & + & + & + & + & + & + & ++ & + & + & + & + & $++t$ & & + & + & + & ++ & + \\
\hline NM110b & + & + & + & + & & & & + & + & + & + & & $+t+$ & + & + & + & + & $+t$ & $+t$ \\
\hline NM4l & + & + & + & & & & & $+t$ & + & + & + & ++ & $+t+$ & & & + & & ++ & 1 \\
\hline NM109 & & + & + & & & & & ++ & + & + & + & ++ & $+t+$ & & & + & & ++ & + \\
\hline
\end{tabular}

* Number of carbons in the parent mycolic acid. $†$ Number of double bonds in the mycolic acid.

Table 5. API ZYM assay results for actinomycetes

\begin{tabular}{|c|c|c|c|c|c|c|c|c|c|c|c|c|c|c|c|c|c|c|c|}
\hline \multirow[b]{2}{*}{ Strain* } & \multicolumn{19}{|c|}{ API enzyme number $\dagger$} \\
\hline & 2 & 3 & 4 & 5 & 6 & 7 & 8 & 9 & 10 & 11 & 12 & 13 & 14 & 15 & 16 & 17 & 18 & 19 & 20 \\
\hline Nocardia pinensis & - & + & + & - & + & - & \pm & - & - & + & + & - & - & - & + & - & - & + & - \\
\hline Nocardia amarae & + & + & + & + & + & - & $\bar{t}$ & - & - & + & + & - & - & - & + & + & - & - & - \\
\hline Rhodococcus rhodochrous & \pm & + & + & \pm & + & + & \pm & - & - & + & + & - & - & - & + & + & - & - & - \\
\hline 'Gordona aurantiaca' & $\bar{t}$ & + & + & $\bar{t}$ & + & - & $\overline{-}$ & - & - & + & + & - & - & - & + & + & - & + & - \\
\hline Corynebacterium equi & + & + & + & - & + & + & + & - & - & + & + & - & - & - & + & + & - & - & - \\
\hline
\end{tabular}

* The strains of $N$. pinensis used were all those listed in Table 1; strains UQM3063 and NM170 were duplicated and gave identical results. For $N$. amarae, the strains were UQM2810, NM26, NM86, NM206, NM296; for $R$. rhodochrous, UQM2807, UQM2808; and for C. equi, UQV 1002 and UQV1092.

† Enzymes were: 1, control; 2, phosphatase alkaline; 3, esterase (C4); 4, esterase lipase (C8); 5, lipase (C14); 6 , leucine arylamidase 7 , valine arylamidase $; 8$, cystine arylamidase $; 9$, trypsin $; 10$, chymotrypsin; 11 , phosphatase acid; 12 , phosphoamidase; $13, \alpha$-galactosidase; $14, \beta$-galactosidase; $15, \beta$-glucuronidase, $16, \alpha$-glucosidase; 17 , $\beta$-glucosidase; $18, N$-acetyl- $\beta$-glucosaminidase; $19, \alpha$-mannosidase ; $20, \alpha$-fucosidase.

\section{API $Z Y M$}

The results for the API ZYM assays are shown in Table 5. The $N$. pinensis strains gave uniform results for the enzymes and were positive for esterase, esterase lipase, leucine arylamidase, acid phosphatase, phosphoamidase, $\alpha$-glucosidase and $\alpha$-mannosidase. Major variations in the results between $N$. pinensis and $N$. amarae were in the enzymes $\beta$-glucosidase and $\alpha$-mannosidase. The $N$. amarae strains gave strong positive results for $\beta$-glucosidase but were negative for $\alpha$-mannosidase. Although both groups were positive for acid phosphatase and phosphoamidase, the $N$. amarae strains were consistently strongly positive whilst the $N$. pinensis strains were weakly positive. The results for the reference Corynebacterium equi strains agreed with published results (Mutimer \& Woolcock, 1982).

Pigment spectra, growth temperature determinations and ability to grow on different media

The orange pigments extracted from $N$. pinensis absorbed maximally at $470 \mathrm{~nm}$. They were not flexirubin-type pigments according to the reaction with $20 \%(\mathrm{w} / \mathrm{v}) \mathrm{KOH}$. It was concluded that the pigment of $N$. pinensis was carotenoid in nature because of its absorption spectrum (Stanier et al., 1977).

The minimum growth temperature for $N$. pinensis was $15^{\circ} \mathrm{C}$, the maximum was $31^{\circ} \mathrm{C}$ with optimum growth between 18 and $25^{\circ} \mathrm{C}$.

Strains of $N$. pinensis could not grow on Sabouraud's dextrose agar, malt agar plus $0.5 \%$ glucose, corn meal agar plus $0.5 \%$ glucose, corn meal agar plus $1 \%$ Tween 80 'Microthrix' 
medium (Slijkhuis, 1983). Scant growth was recorded for $N$. pinensis on medium I of van Veen $e t$ al. (1982). These strains grew on oatmeal agar, tyrosine agar, peptone yeast extract iron agar, blood agar, chocolate agar, inorganic salts starch agar, GSP medium (Trick \& Lingens, 1984), surfactant medium (Zajic et al., 1977) and medium M69 (Scheff et al., 1984). Good growth was recorded for $N$. pinensis on TYG, isosensitest agar, medium 2 of Gledhill \& Casida (1969), trypticase soy agar, yeast malt extract agar, PPLO agar and glycerol asparagine agar base plus $1 \%$ glycerol. Isosensitest agar was an Oxoid product whilst the remaining media listed above without references were Difco Bacto products.

There was no difference in the amount of growth or the pigment of the cultures on TYG incubated in the light or dark and strains grew as well in the air as in the $\mathrm{CO}_{2}$ amended atmosphere. The cultures failed to grow anaerobically, microaerophilically or in the candle jar,

\section{DISCUSSION}

$N$. pinensis is morphologically, biochemically, and in chemotaxonomic properties, different from $N$. amarae, but it is found in predominance in foams on the surface of aeration tanks at activated sludge plants, a feature which it has in common with $N$. amarae. The microcolonies of $N$. pinensis and $N$. amarae showed differences in mycelial morphology (Figs 2 and 3). Filaments of $N$. pinensis contained vesicles; this is not uncommon in actinomycetes and is thought to be a characteristic cellular reaction to age or toxicity of the medium constituents (Goodfellow \& Cross, 1984). TYG, being a complex medium, may contain toxic constituents which could vary between medium batches thus affecting the growth rate of $N$. pinensis.

Media that supported the growth of many nocardiae and those used in the identification of these organisms were generally unsuitable as either growth media or as identification media for $N$. pinensis. TYG, the first medium found to support the growth of $N$. pinensis, was used as the basal medium for many of the biochemical tests. Its possible toxic properties may explain some of the negative results obtained for the biochemical tests. $N$. pinensis grew best on a medium containing glycerol as carbon source and asparagine as nitrogen source and this feature is in common with the mycobacteria (Ratledge, 1982); however, the reason for this preference is unknown. It is postulated that glycerol uptake is passive and not carrier mediated.

Using the conventional identification methods of Gordon (1967), N. amarae produces acid from glucose (aerobic), glycerol, maltose, mannitol, mannose and salicin (Goodfellow et al., 1982); however, these are not the results obtained when the methods described in the present paper are used (Table 2). The basal medium for the acid production from carbohydrates tests was modified to facilitate the growth of $N$. pinensis. The results obtained using these latter methods show differences between $N$. amarae and $N$. pinensis (Table 2) and that the metabolism of $N$. pinensis is oxidative. The inclusion of complex ingredients in the test medium (tryptone and yeast extract) could be contributing to the different results with $N$. amarae. A defined basal medium that supports the growth of $N$. pinensis is required to determine acid production from carbohydrates.

Attempts to extract the cellular DNA from $N$. pinensis failed as the actinomycetes could not be lysed. Classical actinomycete lysis methods (Mordarski et al., 1976; Marshall et al., 1981) were unsuccessful. Modification to these protocols included extension of the time, and manipulation of the temperatures of exposure, to various key lysis ingredients. The cells of $N$. amarae were successfully lysed. Lysis of many different bacteria can be difficult, particularly within the actinomycetes. $N$. pinensis appears to be especially difficult; however, new methods and enzymes for cell lysis are becoming available all the time and hence these need to be evaluated with this organism. The extreme resistance to lysis highlights another difference between $N$. pinensis and other nocardiae.

Both $N$. amarae and $N$. pinensis are slightly different to most other nocardiae in that their mycolic acids have major amounts of mono-unsaturation in the 2-branch. The type strains of N. carnea and N. vaccinii share this property (Lechevalier \& Lechevalier, 1974; Goodfellow \& Lechevalier, 1986). Furthermore, the mycolic acids of $N$. pinensis are slightly longer (58-64 carbons) than those reported for the genus Nocardia (44-60 carbons; Goodfellow \& Lechevalier, 1986). 
Recent studies (Howarth et al., 1986; Collins et al., 1987) have shown that the menaquinones from strains of Nocardia have an unusual structure with cyclization of the two terminal isoprene units. These menaquinones, II, III-tetrahydro- $\omega$-(2,6,6-trimethylcyclohex-2-enylmethyl)-menaquinone-6, abbreviated to $\omega$-cyclo- $\mathrm{MK}-8\left(\mathrm{H}_{4}\right)$, contain eight isoprene units, two hydrogenated $\left(\mathrm{H}_{4}\right)$ and the terminal $(\omega)$ pair cyclized. The characteristic mass spectral peak at $m / z 584$, found for the menaquinones from $N$. pinensis and other members of the genus Nocardia (Collins et al., 1977), is explained by the loss of the $\omega$-cyclized pair of isoprene units (Howarth et al., 1986).

Although Goodfellow \& Cross (1984) and Goodfellow \& Lechevalier (1986) give differing descriptions for the term 'nocardioform', the description of $N$. pinensis fits both. This new organism contains mycolic acids and therefore must belong in one of the following taxa: Mycobacterium, Nocardia, Rhodococcus, Corynebacterium, Caseobacter or the 'aurantiaca' taxon. A combination of the following chemotaxonomic and morphological features was used to align the new strains with Nocardia rather than the other mycolic acid containing taxa: size of mycolic acids, presence of tuberculostearic acid, phosphatidylethanolamine, the very characteristic menaquinones $\left(\omega\right.$-cyclo-MK-8( $\left.\left.\mathrm{H}_{4}\right)\right)$, presence of aerial mycelium and relatively slow rate of mycelial fragmentation. The reasons for its inclusion in Nocardia rather than the close relative Rhodococcus are as follows.

The mycolic acids of $N$. pinensis are slightly longer than those of 'true' nocardiae and the presence of major amounts of unsaturation in the 2-branch is not 'characteristic' for either Nocardia or Rhodococcus. However, of the nine species of Nocardia listed in Bergey's Manual of Systematic Bacteriology (Goodfellow \& Lechevalier, 1986), three have this attribute whilst this is not reported in Rhodococcus. Furthermore, although it is true that susceptibility to lysozyme $\left(50 \mu \mathrm{g} \mathrm{ml}^{-1}\right)$, 5-fluorouracil $\left(20 \mu \mathrm{g} \mathrm{ml}^{-1}\right)$ and mitomycin-C $\left(5 \mu \mathrm{g} \mathrm{ml}^{-1}\right)$ are features shared by some species of Rhodococcus but not by some species of Nocardia (Tsukamura, 1981 $a, b$; Gordon \& Barnett, 1977), they are characters of $N$. amarae. Isoniazid resistance $\left(20 \mu \mathrm{g} \mathrm{ml}^{-1}\right)$ is a property shared by some 34 rhodococci and 10 nocardiae (Orlean et al., 1978); furthermore, this is a property of $N$. amarae. None of the $N$. pinensis strains showed isoniazid resistance. Rifampicin resistance $\left(20 \mu \mathrm{g} \mathrm{m}^{-1}\right)$ was reported for 225 of 230 'true' nocardiae (Gordon \& Barnett, 1977). This feature is not characteristic for either $N$. amarae or $N$. pinensis.

There have been problems in accepting $N$. amarae as a 'true' Nocardia (Goodfellow et al., 1982; Goodfellow \& Cross, 1984; Goodfellow \& Lechevalier, 1986) and the antimicrobial sensitivity patterns reported for $N$. amarae in this paper add to that dilemma as they do not fit those obtained for 'true' nocardiae.

The biochemical, morphological and chemotaxonomic data obtained for the $N$. pinensis strains do not unequivocally align them with Nocardia or Rhodococcus. However, because there are obvious parallels and similarities between our novel strains and $N$. amarae and because there are more chemotaxonomic and morphological attributes shared by the new strains and Nocardia (vide supra) than are common to them and Rhodococcus, we have aligned the strains with the genus Nocardia. Atypical nocardial features are the unusual mycolic acids, the antimicrobial sensitivity patterns, the inability to be lysed by conventional actinomycete lysis methods and the inability to be identified by the conventional methods.

The separation between $N$. amarae and $N$. pinensis is easily facilitated by API ZYM profile comparison, nutritional requirements, menaquinone type, size of mycolic acids and microscopic and macroscopic appearance of the filaments in the sewage plant and on laboratory media. $N$. pinensis can be separated from $N$. vaccinii and $N$. carnea on the basis of nutritional requirements, length of mycolic acids, lysozyme sensitivity and urease production.

$N$. pinensis cannot be identified using the classical media and methods for biochemical characterization of Nocardia (Gordon et al., 1974, 1978; Lechevalier \& Lechevalier, 1974), indicating that it is a new taxon. Therefore, on the basis of chemical and biological evidence, the organism that was isolated by micromanipulation from the foams and mixed liquors of activated sludge sewage treatment plants in Australia is described as a new species of Nocardia.

\section{Description of Nocardia pinensis sp. nov.}

The name Nocardia pinensis sp. nov. (M.L. n. Pinus genus of pine trees; M.L adj. pinensis pertaining to pines and specifically pine tree like in microscopic morphology) is proposed. The 
type strain is UQM3063 deposited in the University of Queensland, Department of Microbiology Culture Collection.

In an activated sludge plant where the organism may proliferate as an extensive surface scum or foam, the microscopic appearance of the filaments resembles a pine tree. The filaments are Gram-positive, non-acid-fast, non-motile, non-sheathed and about $0.5-1.0 \mu \mathrm{m}$ in width. In a Gram stained preparation using acetone as decolourizer, the filaments appear blue as compared to $N$. amarae, which is dark blue or black. Cells from the activated sludge plant or from artificial culture media contain intracellular sudanophilic and polyphosphate inclusions. On TYG solid medium the strains may take $10-21 \mathrm{~d}$ to produce colonies that are about $1-2 \mathrm{~mm}$ in diameter, with the growth rate being variable. The colonies are orange, opaque, macroscopically dry and friable, microscopically moist and shiny, with a pasty texture, not adherent to the agar, difficult to emulsify or subculture, circular with an entire edge. When picked from the agar surface, the whole colony can be removed intact. The majority of the colonies are about $1 \mathrm{~mm}$ in diameter; however, some colonies that are 3-4 mm in diameter occur. Good growth occurs on a defined medium containing glycerol as a carbon source and asparagine as a nitrogen source. In TYG liquid medium the organisms grow as macroscopically visible colonies in a slightly turbid liquid. The strains are positive for catalase, oxidase and urease, and their metabolism is oxidative. Maximum and minimum growth temperatures are $31{ }^{\circ} \mathrm{C}$ and $15^{\circ} \mathrm{C}$, respectively, whilst the optimum lies between 18 and $25^{\circ} \mathrm{C}$. Strains do not degrade hypoxanthine, xanthine, tyrosine, casein, gelatin or aesculin, reduce nitrate or hydrolyse the Tweens $20,40,60$ or 80 when the basal medium is TYG. Strains do not grow in the presence of rifampicin $\left(20 \mu \mathrm{g} \mathrm{ml}^{-1}\right)$, mitomycin-C $\left(5 \mu \mathrm{g} \mathrm{ml}^{-1}\right), 5$-fluorouracil $\left(20 \mu \mathrm{g} \mathrm{ml}^{-1}\right)$ or isoniazid $\left(200 \mu \mathrm{g} \mathrm{ml}^{-1}\right)$ with TYG as basal medium; or in the presence of lysozyme $\left(50 \mu \mathrm{g} \mathrm{ml}^{-1}\right)$ using glycerol broth as basal medium. No growth occurs anaerobically, microaerophilically or in a candle jar; and growth is not enhanced in an atmosphere of $5 \% \mathrm{CO}_{2}$. Based upon chemotaxonomy, the strains contain peptidoglycan type Al $\gamma$, cell wall type IV, whole cell sugar pattern type A, phospholipid type PII, menaquinones $\omega$-cyclo-MK-8$\left(\mathrm{H}_{4}\right)$, fatty acids comprising straight chain saturated and unsaturated acids and tuberculostearic acid, and mycolic acids with 58-64 carbons containing substantial amounts of unsaturated chains in the 2-position. Using the API ZYM testing protocol the strains contain esterase (C4), esterase lipase (C8), leucine arylamidase, phosphatase acid, phosphoamidase, $\alpha$-glucosidase and $\alpha$-mannosidase.

We wish to thank P. Kelly and S. H. Addison for mass spectroscopy and Ms J. Westcott for operation of the electron microscope.

\section{REFERENCES}

ANonymous (1969). Milwaukee mystery: unusual operating problem develops. Water and Sewage Works 116, 213.

Blackbeard, J. R., Ekama, G. A. \& Marais, G. vR. (1986). A survey of filamentous bulking and foaming in activated sludge plants in South Africa. Water Pollution Control 85, 90-100.

Burdon, K. L. (1946). Fatty material in bacteria and fungi revealed by staining dried, fixed slide preparations. Journal of Bacteriology 52, 665-678.

Christensen, W. B. (1946). Urea decomposition as a means of differentiating Proteus and paracolon cultures from each other and from Salmonella and Shigella types. Journal of Bacteriology 52, 461-466.

Collins, M. D., Pirouz, T., Goodfellow, M. \& Minnikin, D. E. (1977). Distribution of menaquinones in actinomycetes and corynebacteria. Journal of General Microbiology 100, 221-230.

Collins, M. D., Howarth, O. W., Grund, E. \& KROPPENSTEDT, R. M. (1987). Isolation and structural determination of new members of the vitamin $\mathrm{K}_{2}$ series in Nocardia brasiliensis. FEMS Microbiology Letters 41, 35-39.
Cruickshank, R., Duguid, J. P., Marmion, B. P. \& SwaIN, R. H. A. (1975). Staining methods. In Medical Microbiology, vol. II, pp. 31-57. New York: Churchill Livingstone.

Dhaliwal, B. S. (1979). Nocardia amarae and activated sludge foaming. Journal Water Pollution Control Federation 51, 344-350.

Dobson, G., Minnikin, D. E., Minnikin, S. M., Parlett, J. H. \& Goodfellow, M. (1985). Systematic analysis of complex mycobacterial lipids. In Chemical Methods in Bacterial Systematics, pp. 237265. Edited by M. Goodfellow \& D. E. Minnikin. London: Academic Press.

Ferguson, E. H. (1980). Actinomycetes of sewage treatment plants. Paper presented to the Queensland Branch of the Australian Water and Wastewater Association, $7 \mathrm{pp}$.

Gledhill, W. E. \& Casida, L. E. (1969). Predominant catalase-negative soil bacteria. III. Agromyces, gen. $\mathrm{n}$., microorganisms intermediary to Actinomyces and Nocardia. Applied Microbiology 18, 340-349.

GoOdFellow, M. \& Cross, T. (1984). Classification. In The Biology of the Actinomycetes, pp. 7-164. 
Edited by M. Goodfellow, M. Mordarski \& S. T. Williams. London: Academic Press.

Goodfellow, M. \& Lechevalier, M. P. (1986). The genlis Nocardia Trevisan 1889, $9^{\mathrm{AL}}$. In Bergey's Manual of Systematic Bacteriology vol. 2, pp. 14591471. Edited by P. H. A. Sneath. Baltimore: Williams \& Wilkins.

Goodfellow, M., Minnikin, D. E., Todd, C., Alderson, G., Minnikin, S. M. \& Collins, M. D. (1982). Numerical and chemical classification of Nocardia amarae. Journal of General Microbiology 128, 1283-1297.

GORDON, R. E. (1967). The taxonomy of bacteria. In The Ecology of Soil Bacteria, pp. 293-321. Edited by T. Gray, R. G. Parkinson \& B. Parkinson. Liverpool: Liverpool University Press.

GORDON, R. E. \& BARNETT, D. A. (1977). Resistance to rifampin and lysozyme of strains of some species of Mycobacterium and Nocardia as a taxonomic tool. International Journal of Systematic Bacteriology 27, 176-178.

Gordon, R. E., Barnett, D. A., Handerhan, J. E. \& PANG, C. H.-N. (1974). Nocardia coeliaca, Nocardia autotrophica and the nocardin strain. International Journal of Systematic Bacteriology 24, 54-63.

Gordon, R. E., Mishra, S. K. \& BarnetT, D. A. (1978). Some bits and pieces of the genus Nocardia: $N$. carnea, $N$. vaccinii, $N$. transvalensis, $N$. orientalis and $N$. aerocolonigenes. Journal of General Microbiology 109, 69-78.

HaRper, J. J. \& Davis, G. H. G. (1979). Twodimensional thin-layer chromatography for amino acid analysis of bacterial cell walls. International Journal of Systematic Bacteriology 29, 56-58.

HART, M. A. (1985). Scum formation in a nutrient removing activated sludge plant. Water South Africa 11, 171-178.

HARTLEY, K.J. (1982). Nocardia in activated sludge plants. Paper presented to 1982 Queensland Local Authority Engineers Conference Proceedings, pp. 109-132.

Howarth, O. W., Grund, E., Kroppenstedt, R. M. \& Collins, M. D. (1986). Structural determination of a new naturally occurring cyclic vitamin $\mathrm{K}$. Biochemical and Biophysical Research Communications 140, 916-923.

LeChevalier, H. A. (1975). Actinomycetes of sewage treatment plants. US Dept. of Commerce National Technical Information Service Report no. PB 245914.

Lechevalier, M. P. \& Lechevalier, H. A. (1974). Nocardia amarae sp. nov., an actinomycete common in foaming activated sludge. International Journal of Systematic Bacteriology 24, 278-288.

LEMmer, H. \& KROPPENSTEDT, R. M. (1984). Chemotaxonomy and physiology of some actinomycetes isolated from scumming activated sludge. Systematic and Applied Microbiology 5, 124-135.

Marshall, R. B., Wilton, B. E. \& Robinson, A. J. (1981). Identification of leptospira serovars by restriction endonuclease analysis. Journal of Medical Microbiology 14, 163-166.

Minnikin, D. E., Alshamaony, L. \& Goodfellow, M. (1975). Differentiation of Mycobacterium, Nocardia and related taxa by thin-layer chromatographic analysis of whole-organism methanolysates. Journal of General Microbiology 88, 200-204.
Minnikin, D. E., Hutchinson, L. G., Caldicott, A. B. \& Goodfellow, M. (1980). Thin-layer chromatography of methanolysates of mycolic acidcontaining bacteria. Journal of Chromatography 188, 221-233.

Minnikin, D. E., Minnikin, S. M. \& Goodfellow, M. (1982). The oxygenated mycolic acids of $\mathrm{Myco}^{-}$ bacterium fortuitum, $M$. farcinogenes and $M$. senegalense. Biochimica et biophysica acta 712, 616-620.

Minnikin, D. E., O'Donnell, A. G., Goodfellow, M., Alderson, G., Athalye, M., Schaal, A. \& Parlett, J. H. (1984). An integrated procedure for the extraction of bacterial isoprenoid quinones and polar lipids. Journal of Microbiological Methods 2, 233-241.

Mordarski, M., Szyba, K., Pulverer, G. \& GoodFELLOW, M. (1976). Deoxyribonucleic acid reassociation in the classification of the 'rhodochrous' complex and allied taxa. Journal of General Microbiology 94, 235-245.

Mutimer, M. D. \& Woolcock, J. B. (1982). API ZYM for identification of Corynebacterium equi. Zentralblatt für Bakteriologie und Hygiene, Abteilung I, Originale C 3, 410-415.

Nahaie, M. R., Goodfellow, M., Minnikin, D. E. \& HAJEK, V. (1984). Polar lipid and isoprenoid quinone composition in the classification of Staphylococcus. Journal of General Microbiology 130, 2427-2437.

Nelson, J. K. (1979). Start-up and operation of Denver's pure oxygen-activated sludge plant. Journal Water Pollution Control Federation 51, 907 917.

Orlean, P. A. B., Goodfellow, M. \& Minnikin, D. E. (1978). Isoniazid susceptibility as a criterion for the differentiation of mycobacterial species from other mycolic acid containing taxa. International Journal of Systematic Bacteriology 28, 194-196.

PIPES, W. O. (1978). Actinomycete scum production in activated sludge processes. Journal Water Pollution Control Federation 50, 628-634.

RATLEDGE, C. (1982). Nutrition, growth and metabolism. In The Biology of the Mycobacteria, vol. 1, pp. 185-271. Edited by C. Ratledge \& J. Stanford. London: Academic Press.

Reichenbach, H., Kohl, W. \& Achenbach, H. (1981). The flexirubin-type pigments, chemosystematically useful compounds. In The Flavobacterium-Cytophaga Group (GBF Monograph Series no. 5), pp. 101-108. Edited by H. Reichenbach \& O. B. Weeks. Weinheim: Verlag Chemie.

SCHEFF, G., Salcher, O. \& Lingens, F. (1984). Trichococcus flocculiformis gen. nov. sp. nov. A new gram-positive filamentous bacterium isolated from bulking sludge. Applied Microbiology and Biotechno$\log y$ 19, 114-119.

SIERRA, G. (1957). A simple method for the detection of lipolytic activity of micro-organisms and some observations on the influence of the contact between cells and fatty substrates. Antonie van Leeuwenhoek 23, $15-22$.

Skerman, V. B. D. (1967). A Guide to the Identification of Genera of Bacteria, 2nd edn. Baltimore: Williams \& Wilkins.

Skerman, V. B. D. (1968). A new type of micromanipulator and microforge. Journal of General Microbiology 54, 287-297. 
SLIJKHUIS, H. (1983). Microthrix parvicella, a filamentous bacterium isolated from activated sludge: cultivation in a chemically defined medium. Applied and Environmental Microbiology 46, 832-839.

SNEATH, P. H. A. (1956). Cultural and biochemical characteristics of the genus Chromobacterium. Journal of General Microbiology 15, 70-98.

Staneck, J. L. \& RoberTs, G. D. (1974), Simplified approach to the identification of aerobic actinomycetes by thin-layer chromatography. Applied Microbiology 28, 226-231.

Stanier, R. Y., Adelberg, E. A. \& Ingraham, J. L. (1977). General Microbiology, 4th edn. London: Macmillan.

TRICK, I. \& Lingens, F. (1984). Characterization of Herpetosiphon spec.-a gliding filamentous bacterium from bulking sludge. Applied Microbiology and Biotechnology 19, 191-198.

Tricker, T. D. A. \& Thorpe, A. H. (1979). The commissioning and operation of Belper Sewage Treatment Works. Water Pollution Control 78, 515 523.
Tsukamura, M. (1981a). Differentiation between the genera Mycobacterium, Rhodococcus and Nocardia by susceptibility to 5-fluorouracil. Journal of General Microbiology 125, 205-208.

TsuKamura, M. (1981b). Test for susceptibility to mitomycin $\mathrm{C}$ as aids for differentiating the genus Rhodococcus from the genus Nocardia, and for differentiating Mycobacterium fortuitum and $\mathbf{M y c o -}$ bacterium chelonei from other rapidly growing mycobacteria. Microbiology \& Immunology 25, 1197-1199.

van Veen, W. L., Krul, J. M. \& Bulder, C. J. E. A. (1982). Some growth parameters of Haliscomenobacter hydrossis (syn. Streptothrix hyalina) - a bacterium occurring in bulking activated sludge. Water Research 16, 531-534.

Zajic, J. E., Guignard, H. \& Gerson, D. F. (1977). Emulsifying surface active agents from Corynebacterium hydrocarboclasters. Biotechnology and Bioengineering 19, 1285-1301. 